\title{
Genotype-specific incidence and clearance rates of human papilloma virus (HPV) infection in HIV- infected women from Pune, India
}

\author{
Arati Mane ${ }^{1 *}$, Amit Nirmalkar ${ }^{1}$, Arun R Risbud ${ }^{1}$, Sten H Vermund ${ }^{2}$, Sanjay M Mehendale ${ }^{3}$, Vikrant V Sahasrabuddhe ${ }^{2}$ \\ From First International Science Symposium on HIV and Infectious Diseases (HIV SCIENCE 2012) \\ Chennai, India. 20-22 January 2012
}

\section{Background}

Information on HPV genotype-specific incidence and clearance is important to better inform the natural history of cervical neoplasia in context of HIV/AIDS. We conducted a cohort study among HIV-infected women in Pune, India to estimate the genotype-specific HPV incidence and clearance rates.

\section{Methods}

HIV-infected women underwent baseline and annual follow-up visits for cervical cancer screening and collection of cervicovaginal samples for detection of $37 \mathrm{HPV}$ genotypes by Linear Array polymerase chain reaction (PCR) assay.

\section{Results}

A total of 215 eligible participants were followed for a median time of 11 months (range: 8-23 months) with a follow-up period of 223 person-years. Of the 104/215 (48.4 \%) HIV-infected women who were HPV-negative at baseline, 12 women were newly detected with HPV at follow-up visit reflecting an incidence rate of 5.4 per 100 person-years. Type-specific incidence rates ranged between 0.45-3.42 per 100 person-years for carcinogenic HPV types and between 0.45-1.79 per 100 person-years for other HPV types. Of the 111/215 (51.6 \%) women with HPV at baseline, 21 women cleared all types, reflecting a clearance rate of 9.4 per 100 person-years. Type-specific clearance rates ranged between 0.45-4.48 per 100 person-years for carcinogenic HPV types and between 0.45-4.04 for other HPV types.

* Correspondence: amane@nariindia.org

${ }^{1}$ National AIDS Research Institute, Pune, India

Full list of author information is available at the end of the article

\section{Conclusions}

This study adds to the scant global data of natural history of HPV infection in HIV-infected women. Knowledge of incidence and clearance rates can inform cost effectiveness and decision analysis models for estimating effectiveness of HPV vaccination and screening strategies for cervical cancer prevention for HIV-infected women.

\section{Author details}

${ }^{1}$ National AIDS Research Institute, Pune, India. ${ }^{2}$ Vanderbilt University Institute for Global Health, Nashville, USA. ${ }^{3}$ National Institute of Epidemiology, Chennai, India.

Published: 4 May 2012

\section{doi:10.1186/1471-2334-12-S1-O2}

Cite this article as: Mane et al:: Genotype-specific incidence and clearance rates of human papilloma virus (HPV) infection in HIVinfected women from Pune, India. BMC Infectious Diseases 2012 12(Suppl 1):O2.

Submit your next manuscript to BioMed Central and take full advantage of:

- Convenient online submission

- Thorough peer review

- No space constraints or color figure charges

- Immediate publication on acceptance

- Inclusion in PubMed, CAS, Scopus and Google Scholar

- Research which is freely available for redistribution 